\begin{tabular}{|l|l|l|}
\hline \multicolumn{2}{|c|}{ PublisherInfo } \\
\hline \hline PublisherName & $:$ & BioMed Central \\
\hline \hline PublisherLocation & $:$ & London \\
\hline \hline PublisherImprintName & $:$ & BioMed Central \\
\hline \hline
\end{tabular}

\title{
Enhancing the hominoid brain
}

\begin{tabular}{|l|l|l||}
\hline \multicolumn{2}{|c|}{ ArticleInfo } \\
\hline \hline ArticleID & $:$ & 5002 \\
\hline \hline ArticleDOI & $:$ & $10.1186 /$ gb-spotlight-20040921-01 \\
\hline \hline ArticleCitationID & $:$ & spotlight-20040921-01 \\
\hline \hline ArticleSequenceNumber & $:$ & 65 \\
\hline \hline ArticleCategory & $:$ & Research news \\
\hline ArticleFirstPage & $:$ & 1 \\
\hline \hline ArticleLastPage & $:$ & 3 \\
\hline \hline & & RegistrationDate : 2004-9-21 \\
\hline ArticleHistory & $:$ & OnlineDate \\
\hline \hline ArticleCopyright & $:$ & BioMed Central Ltd2004-9-21 \\
\hline \hline ArticleGrants & $:$ & \\
\hline \hline ArticleContext & $:$ & 130595511 \\
\hline \hline
\end{tabular}


Melissa Phillips

Email: mlphilli@u.washington.edu

The birth of a gene that fueled neurotransmission may have been a key advance in the evolution of the hominoid brain, according to a study in the October issue of Nature Genetics. The study reveals that a human and ape brain gene involved in glutamate metabolism was retrotransposed from a widely expressed housekeeping gene in the beginning of the hominoid lineage (Nat Genet 2004, 36:1061-1063).

Henrik Kaessmann and Fabien Burki of the University of Lausanne, Switzerland, detected the gene, GLUD2, in humans and apes, but not in Old World monkeys, indicating that the gene appeared after monkeys and hominoids went their separate ways - about 23 million years ago - but before the gibbon lineage split from humans and great apes around 18 million years ago.

After the retrotransposition, the new glutamate metabolism enzyme, called GLUD2, went through several million years of positive Darwinian selection, say the authors. By combining these new genetic data with previous functional analyses of GLUD2, they show that GLUD2 acquired amino acid changes that increased glutamate flux, possibly enhancing cognitive function in the hominoid brain.

Kaessmann and Burki propose that GLUD2's birth and evolution may be related to a period of increased overall brain size, as well as increased structural and functional complexity, in the human and ape ancestor. "Quite a lot happened around the emergence of the hominoids," Kaessmann told us. "The foundation for the very recent enlargement of the human brain - within the past 2 million years or so was laid much earlier."

The study "really makes a functional connection," Svante Pääbo of the Max Planck Institute for Evolutionary Anthropology in Leipzig, Germany, told us. "There are a number of other genes that have been shown to be positively selected in humans or apes, but here they actually show the two amino acid changes that conferred to GLUD2 the brain-specific abilities," said Pääbo, who was not involved in the study.

GLUD2 and its parent, GLUD1, are glutamate dehydrogenases that take up glutamate into astrocytes after neuron firing. GLUD2 resides on the X chromosome and has no introns - a clue that it was probably copied from spliced mRNA of the housekeeping GLUD1. Since the retrotransposition, the GLUD1 protein sequence has been conserved completely in humans and apes. GLUD2, however, immediately entered a period of accelerated evolution.

In a News and Views article accompanying the paper, Ajit Varki, a glycobiologist at the University of California, San Diego, speculates that GLUD2 might have inserted by chance next to a brain-specific promoter in the $\mathrm{X}$ chromosome and was then fine tuned for breaking down glutamate in the brain.

Previous functional work has shown that GLUD2, unlike GLUD1, functions well in high guanosine 5 -triphosphate concentrations, is a ctivated by the low-energy signal adenosine disphosphate, and is most active at a neutral $\mathrm{pH}$ - all features of the environment inside an astrocyte just after neuron firing. The study also revealed that changing just two amino acids in GLUD1 permits the enzyme to metabolize the brain's glutamate almost as well as GLUD2, Kaessmann said. Kaessmann and Burki's analysis shows 
that these two residue changes occurred in the first few million years after duplication, so all hominoids possess them.

The study doesn't prove that GLUD2's effects on glutamate transmission are related to an increase in brain size or structural complexity, said Bruce Lahn, an evolutionary geneticist at the University of Chicago who was not involved in the study, "but I think it's fair to speculate."

There is other evidence of the importance of GLUD2 in brain function, according to Kaessmann. Reduced GLUD2 in the brain - resulting in excess glutamate - has been associated with several neurodegenerative disorders. And recent memory experimentsin rats identified glutamate dehydrogenase as one of only two genes upregulated during memory formation as the rats learned to navigate mazes.

With "another gene that functions much better, actually, than GLUD1 in the brain in these few primate species, including us humans, we might then have a direct advantage in forming memories," Kaessmann said. "We have to of course be careful - we don't really know."

"This was a new gene, it was positively selected, and it's really linked to neuronal activity," Pääbo said. "It's quite likely that it has actually contributed to human cognitive function."

\section{References}

1. Nature Genetics, [http://www.nature.com/ng/]

2. Henrik Kaessmann, [http://www.unil.ch/cig/page7858_en.html]

3. Study of structure-function relationships in human glutamate dehydrogenases reveals novel molecular mechanisms for the regulation of the nerve tissue-specific (GLUD2) isoenzyme

4. Maher BA: Bite makes way for brain Genome Biology, March 26, 2004., [http://genomebiology.com/ researchnews/default.asp?arx_id=gb-spotlight-20040326-01]

5. Svante Pääbo, [http://email.eva.mpg.de/ paabo/index.html]

6. Ajit Varki, [http://cmm.ucsd.edu/varki/biography.html]

7. Bruce Lahn, [http://www.genes.uchicago.edu/fri/lahnres.html]

8. Novel human glutamate dehydrogenase expressed in neural and testicular tissues and encoded by an $\mathrm{X}$-linked intronless gene

9. ate memory-related genes in the hippocampus revealed by RNA fingerprinting

This PDF file was created after publication. 